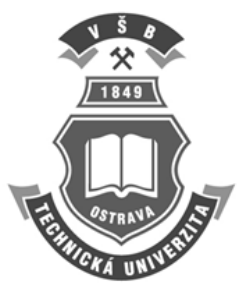

\title{
Analýza volatility devizových kurzů vybraných ekonomik
}

\author{
Radek BEDNǍ̌́́K, VŠB - TU Ostrava ${ }^{\mathrm{i}}$
}

\begin{abstract}
This paper is focused on the historical development of selected exchange rates' volatility, that is: AUD, CAD, DEM, DKK, EUR, FRF, GBP, JPY, SEK and CHF against USD. The paper aims to show that current relatively large increment of foreign exchange markets' volatility is nothing special in the historical context considering the length and the extent of the volatility clusters during turbulent periods. Using various kinds of (G)ARCH models of volatility and subsequent graphical analysis we were able to empirically confirm this statement.
\end{abstract}

\author{
Keywords \\ exchange rates, volatility, GARCH
}

JEL Classification: F31

i Department of National Economy, Faculty of Economics, VŠB-Technical University of Ostrava, Sokolská 33, 70121
Ostrava, Czech Republic.
bednarik.radek@gmail.com
This paper is a part of research study being written for Josef and Marie Hlávkovi Foundation Macroeconomical Impacts of the
Role of Dollar in the International Monetary System and of author's dissertation as well.

\section{1. Úvod}

Volatilita, tj. nestabilita či rozkolísanost devizových kurzi̊, je jev, jehož výskyt je nedílně spjat s existencí flexibilních devizových kurzů. Je zřejmé, že tak jako flexibilní kurzy přinášejí mnoho pozitiv, stejně tak mají i svá negativa.

Volatilita kurzů je jedním z těchto negativ. Přináší totiž s sebou nejistotu, proti které se ekonomické subjekty, jež se nějakým způsobem angažují, a to at' už přímo, či nepř́ímo, na měnových trzích, snaží zajistit. A jelikož takovéto zajištění se proti nepř́iznivým (a neočekávaným) změnám kurzů s sebou nese určité náklady, je problematice analýzy historického vývoje a následně vývoje budoucího věnována značná pozornost nejenom v akademické, ale i v podnikové sfére. Ovšem, stejně tak může přinést dodatečné náklady (ale i výnosy) změna kurzu, proti níž se daný subjekt nezajistil.
Základem pro dnešní modely volatility, tj. různé typy GARCHů a jejich mnoha variací a rozšíření, byla práce Engleho (1982), který zavedl model ARCH (Autoregressive Conditional Heteroskedasticity). Od té doby vznikla řada jeho rozšiřrení, at' už jako lineární, či nelineární modely. Jejich cíl je však vždy stejný co nejlépe zachytit vývoj volatility $\mathrm{v}$ minulosti a na tomto základě se pak pokusit předpovědět budoucí vývoj zkoumané veličiny, např. devizového kurzu, či indexu akciového trhu.

Studií, které se nějakým způsobem zabývaly zkoumáním volatility (měnových) trhů, je značné množství. Ve čtvrté části této práce je podán stručný přehled závěrů některých $\mathrm{z}$ nich. Naprostá většina z nich se nezabývá jen vývojem samotné volatility, ale tuto dává do vztahu s dalšími proměnnými, resp. se tento vztah snaží najít, či empiricky ověřit.

Tato práce se zabývá historickým vývojem volatility vybraných devizových kurzů, konkrétně měn AUD (australský dolar), CAD (kanadský dolar), DEM 
(německá marka), DKK (dánská koruna), EUR (euro), FRF (francouzský frank), GBP (britská libra), JPY (japonský jen), SEK (švédská koruna) a CHF (švýcarský frank) vủči USD (americký dolar). Cílem studie je ukázat, že nynější poměrně značný nárůst volatility na měnových trzích není $\mathrm{v}$ historickém kontextu nic výjimečného, co se délky a rozsahu týče.

Časové řady, které zde zkoumáme, jsou v denních frekvencích a v rozsahu 4. 1.1971 - 14. 7. 2008. ${ }^{1}$ Zdrojem dat byla databáze FRED (Federal Reserve Economic Data) a IFS (International Financial Statistics) Mezinárodního měnového fondu.

Zbytek práce je členěn takto. V první části je rozebrána metodologie výpočtů použitých modelů volatility. Druhá část uvádí přehled současných studií zabývajících se volatilitou devizových kurzů a jejich závěry. Třetí část se pak za použití zvolených modelů a grafického aparátu zabývá vývojem volatility vybraných devizových kurzů v rámci zvoleného období.

\section{Metodologie}

\subsection{Vlastnosti finančních časových řad}

Jelikož v této práci pracujeme výhradně s časovými řadami, resp. s jejich výnosy, je nutné se, alespoň stručně, zmínit o základních a důležitých vlastnostech tohoto typu dat.

Tyto problémy lze řešit zlogaritmováním časové řady a následným diferencováním. Tedy, výnosy finanční časové řady $X_{t}$ lze z původní časové řady $Y_{t}$ vypočíst jako:

$$
X_{t}=\sum_{t=1}^{m}\left[\ln \left(Y_{t}\right)-\ln \left(Y_{t-n}\right)\right],
$$

kde $t$ je číslo pozorování z celkového počtu $m$ pozorování a $n$ je počet zpoždění.

Takto získané časové řady výnosů jsou již v naprosté většině př́ípadů stacionární, tj. mají konstantní střední hodnotu a rozptyl v čase a jejich rozdělení se již velmi blíží rozdělení normálnímu. Nicméně, často je charakterizováno vyšší špičatostí a má „tlustší" konce (fat-tails). To indikuje, že mnohem častější jsou výnosy, jejichž hodnota se pohybuje kolem nuly a taktéž že se s mnohem vyšší pravděpodobností než u normálního rozdělení v dané časové řadě vyskytují extrémní, at' už kladné, či záporné hodnoty.

\footnotetext{
1 Výjimkou jsou kurzy DEM, FRF a EUR, které jsou v měsíčních frekvencích, a z pochopitelných důvodů DEM a FRF končí k prosinci 1998, resp. EUR začíná lednem 1999.
}

\subsection{Modely $\operatorname{ARIMA}(p, d, q)$}

Protože všechny námi zkoumané časové řady nebyly stacionární a jejich rozdělení nebylo normální, byly všechny logaritmovány a diferencovány. U některých časových řad se však při výpočtu volatility dále vyskytovala autokorelace, a proto musely být do funkcí modelů těchto řad zařazeny autoregresní nebo moving-average členy.

Proto je nutné alespoň stručně tento typ modelů časových řad popsat. Obecný tvar takové časové řady, která je modelována autoregresním a moving-average procesem a která je diferencována, lze pak zapsat jako:

$$
X_{t}=\sum_{i=1}^{m} \phi_{i} \cdot X_{t-i}+\sum_{j=0}^{n} \varphi_{j} \cdot a_{t-j},
$$

kde $X_{t-i}$ je hodnota časové řady v čase $t-i ; \phi, \varphi$ jsou parametry a $a_{t-j}$ je chybová složka v čase $t-j .^{2}$

\section{Modely volatility}

Modely volatility, které jsou použity $\mathrm{v}$ této práci, jsou modely tzv. podmíněné heteroskedasticity (conditional heteroskedasticity). Konkrétně, jestliže rozptyl zkoumané časové řady má $\mathrm{v}$ čase proměnlivý charakter a pokud tento rozptyl lze vyjádřit autoregresní formou, pak hovoříme o autoregresně podmíněné heteroskedasticitě (autoregressive conditional heteroskedasticity). Modely zabývající se takto definovanou volatilitou se označují zkratkou $\operatorname{ARCH}(p)$.

\subsection{Model ARCH(q)}

Formálně pak můžeme obecný lineární model $\operatorname{ARCH}(q)$ s $q$ členy $\mathrm{v}$ autoregresní formě pro $n$ zpoždění zapsat takto:

$$
\sigma_{t}^{2}=\omega+\sum_{n=1}^{q} \alpha_{n} \cdot \varepsilon^{2}{ }_{t-n},
$$

kde $\sigma^{2}$ je podmíněný rozptyl reziduí časové řady, $\omega$ je konstanta, $\alpha$ je koeficient a $\varepsilon^{2}$ jsou rezidua. Jelikož podmíněný rozptyl musí být kladné číslo, pak je dáno, že $\omega$ musí být $>0$ a $\alpha_{n}$ musí být $\geq 0$.

Alternativním vyjádřením rovnice (3) je autoregresní tvar:

$$
\varepsilon_{t}^{2}=\omega+\sum_{n=1}^{q} \alpha_{n} \cdot \varepsilon_{t-n}^{2}+v_{t},
$$

kde $v_{t}=\varepsilon_{t}^{2}-\sigma_{t}^{2}$.

\footnotetext{
${ }^{2}$ Respektive $a_{t-j}$ je rozdíl mezi skutečnou hodnotou dané časové řady v čase $t-j$ a střední hodnotou $\mu$. Toto lze vyjádřit Woldovou reprezentací, tj. jako lineární proces, viz Arlt a Arltová (2003, 2007), Palma (2007).
} 
Jak vidíme, tyto modely se vyznačují schopností zachytit shluky volatility (volatility clustering), protože jak vyplývá z (4), jestliže je $\varepsilon_{t-1}^{2}$ nízké, pak lze očekávat, že $\varepsilon_{t}^{2}$ bude také nízké, a naopak.

\subsection{Modely GARCH $(p, q)$}

$\mathrm{U}$ modelů $\operatorname{ARCH}(q)$ někdy vzniká problém, že při modelování zkoumané časové řady je nutné použít parametr $q$ o vysoké hodnotě, což může být výpočetně velmi náročné. Bollerslev (1986) proto vyvinul model $\operatorname{GARCH}(p, q)$, tj. model zobecněného, autoregresně podmíněného rozptylu, kde k původnímu $\operatorname{ARCH}(q)$ modelu přidal zpožděnou hodnotu podmíněného rozptylu. Obecná forma tohoto modelu s $p$ a $q$ členy (resp. zpožděními) má tvar:

$$
\sigma^{2}{ }_{t}=\omega+\sum_{n=1}^{q} \alpha_{n} \cdot \varepsilon^{2}{ }_{t-n}+\sum_{n=1}^{p} \beta_{n} \cdot \sigma_{t-n}^{2},
$$

kde opět $\sigma^{2}$ je podmíněný rozptyl reziduí časové řady, $\omega$ je konstanta, $\alpha$ je koeficient a $\varepsilon^{2}$ jsou rezidua. Stejně jako u rovnice (3) lze rovnici (5) přepsat do alternativní formy.

Předpokládejme, že časová řada výnosů zkoumaného devizového kurzu je definována např. jako autoregresní proces n-tého řádu, tj.:

$$
X_{t}=\sum_{i=1}^{n} \phi_{i} \cdot X_{t-n}+\delta g\left(h_{t}\right)+\varepsilon_{t},
$$

kde $X_{t}$ je výnos zkoumané časové řady, $\phi$ je parametr, $\varepsilon$ je chybová složka s vlastnostmi bílého šumu a $\delta g\left(h_{t}\right)$ je člen, resp. funkce vyjadřující podmíněný rozptyl, počítaný metodou $\operatorname{GARCH}(p, q)$.

Tento model (Engle a kol., 1987) nám tedy umožňuje zachytit vztah mezi úrovní a variabilitou (volatilitou) logaritmů výnosů, pokud na sobě samozřjmě závisí.

\section{Shrnutí závěrů studií volatility devizových kurzů}

V této části studie shrneme závěry plynoucí ze současných prací zabývajících se volatilitou devizových kurzů.

Kalra (2008) se zabývala vztahem volatility vyspělých finančních akciových trhů (konkrétně indexy VIX a VDAX) a denních výnosů bilaterálních nominálních devizových kurzů měn IDR (indonéská rupie), KRW (korejský won), PHP (filipínské peso), SGD (singapurský dolar) a THB (thajský baht) oproti USD. ${ }^{3}$

\footnotetext{
${ }^{3}$ VIX - index volatility CBOE (Chicago Board Options Exchange). Tento index je užíván pro odhad tržních očekávání na trhu aktiv S\&P500.
}

Pro měření podmíněného rozptylu (volatility) shledává nejvhodnější model $\operatorname{GARCH}(1,1)$. Výsledkem studie je závěr, že během let $2001-2007$ výnosy devizových kurzů poklesly, když se volatilita akciových trhů zvýšila. Kalra (2008) odhadla, že 5\% zvýšení volatility akciových trhů je doprovázeno depreciací nominálních bilaterálních devizových kurzů ve výši až 0.5 procenta. Stejně tak ukázala, že tato citlivost se zvyšovala $\mathrm{v}$ čase, což může indikovat rostoucí provázanost asijských finančních trhů se světovými trhy.

Jako klíčové shledává zjištění, že „dlouhodobá volatilita [zkoumaných] devizových kurzů poklesla, zřejmě díky vzpamatování se [z asijské finančních krize] a díky všeobecně „silnějším“ fundamentálním ekonomickým veličinám. Dále díky přechodu k více flexibilním režimům devizového kurzu spolu s nižní úrovní volatility vyspělých akciových trhů.“ (Kalra, 2008, str. 10.)

Cady a Gonzales-Garcia (2006) zkoumali, zda zveřejňování údajů o devizových rezervách a likviditě (International Reserves and Foreign Currency Liquidity Data Template), která jsou v rámci SDDS Mezinárodního měnového fondu členskými zeměmi poskytována od roku 1999, mělo a má vliv na volatilitu nominálních devizových kurzů.

Dle jejich hypotézy existují dva kanály, kterými zveřejňování údajů může působit na volatilitu. Prvním kanálem je zvýšená transparentnost a následné částečné „odbourání“ nervozity účastníků obchodování na devizových trzích.

Druhým kanálem je pak možnost účastníků trhu díky těmto informacím lépe vyhodnocovat (ne)zadluženost dané země a výši adekvátních devizových rezerv.

Panelovou regresí vzorku 48 zemí zjistili, že ${ }^{4}$ za prvé, po zahrnutí možných vlivů v rámci jednotlivých zemí v rámci panelové regrese lze vypozorovat snížení úrovně volatility nominálních devizových kurzů po zavedení povinného zveřejňování údajů o devizových rezervách a likviditě.

Za třetí, regrese potvrdily negativní vztah mezi poměrovým ukazatelem rezerv ke krátkodobému dluhu a volatilitou kurzu. Tento negativní vztah se po zavedení povinnosti zveřejňovat data o rezervách a likviditě dále prohloubil.

VDAX - index pro měření implikované volatility indexu DAX. Je počítán z 30denních opčních kontraktů.

${ }^{4}$ Tyto země zahrnovaly 12 průmyslových a 36 rozvojových a nízkopř́ijmových ekonomik. Data byla čtvrtletního charakteru, v rozsahu od 1. kvartálu 1991 do 4. kvartálu 2005 včetně. 
Stančík (2007) se zabýval vztahem mezi volatilitou bilaterálních nominálních devizových kurzů a skupinou proměnných, do nichž zahrnul otevřenost ekonomiky, faktor „,novinek“ (,news“ factor) a režim devizového kurzu. Volatilita byla modelována pomocí TARCH (treshold autoregressive conditional heteroskedasticity).

Na vzorku pěti zemí (ČR, Mad’arsko, Polsko, Slovensko, Slovinsko), resp. kurzů jejich měn vůči euru, dochází k (nepřekapivým) závěrům, že:

Za prvé, otevřenost ekonomiky má „zklidňující“, tj. negativní ve smyslu vztahu mezi těmito veličinami, vliv na úroveň volatility devizových kurzů.

Za druhé, „novinky“, tj. nové informace, významně ovlivňují volatilitu.

A za třetí, flexibilní režimy devizových kurzů jsou náchylné $\mathrm{k}$ vyšší míře volatility.

Kisinbay (2003) použil pro zkoumání krátko- až střednědobé predikční schopnosti asymetrických modelů volatility časové řady jednoho akciového indexu (TSE - Toronto Stock Exchange) a dvou devizových kurzů (USD/DEM a USD/JPY).

Empirickým testováním různých typů asymetrických modelů vůči symetrickému lineárnímu GARCH modelu na vysokofrekvenčním (intra-day) vzorku dat dospěl k závěru, že: Pro index akciového trhu TSE vykazují asymetrické modely jednoznačně lepší výsledky.

Dále taktéž pro časové řady devizových kurzů je lépe použít asymetrické modely. Pro časovou řadu USD/DEM vykazovaly všechny asymetrické modely, kromě EGARCHu, lepší výsledky než standardní lineární GARCH. Taktéž u řady USD/DEM vykazuje většina asymetrických modelů statisticky lepší výsledky. Nicméně, jak autor uvádí, v prípadě časových řad devizových kurzů jsou zlepšení těchto asymetrických modelů vůči symetrickému zanedbatelná.

\section{Volatilita devizových kurzů vybraných ekonomik}

V této části práce se budeme př́mo zabývat volatilitou, tedy nestabilitou či rozkolísaností devizových kurzů vybraných zemí. Bude použit ekonometrický aparát vyvinutý př́mo pro analýzu volatility časových řad finančních trhů - tj. půjde o různé typy modelů GARCH, jejichž výstupy budeme pro větší přehlednost dále filtrovat pomocí HodrickPrescottova filtru.

Periodicita dat je až na výjimky DEM a FRF, které jsou měsíční, denní. Zdrojem dat byly databáze FRED
(Federal Reserve Economic Data) a IFS Mezinárodního měnového fondu. ${ }^{5}$

Nejprve se podívejme na vývoj zkoumaných kurzů, který nám zachycuje obrázek 1 .

U všech devizových kurzů, s výjimkou JPY a pochopitelně DEM a FRF, můžeme vidět jasný apreciační trend všech zbývajících měn vưči USD během posledních osmi let. Toto pozvolné, ale setrvalé oslabování dolaru vystřídalo dlouhé období posilování USD vůči zkoumaným měnám, které probíhalo zhruba od druhé poloviny 90 . let až do cca poloviny roku 2001. Lze taktéž u většiny kurzů vysledovat jistou cykličnost jejich vývoje.

Oslabení USD je markantní např. u kanadského dolaru, který během období let 2001 - 2008 zcela vymazal své předchozí oslabení, a naopak se stal ještě silnějším než cca v roce 1992, kdy CAD začal setrvale oslabovat. CAD je dokonce nejsilnější vưči USD zhruba od roku 1977.

I euro vykazuje od konce roku 2001 setrvalý posilovací trend vůči USD, což jenom potvrdilo sílu a konkurenceschopnost společné evropské měny.

A nyní pojd'me prrímo $\mathrm{k}$ problematice volatility. Grafický přehled o nestabilitě kurzů vybraných ekonomik vůči dolaru (což samozřejmě platí i naopak!), podávají obrázky 2 a 3 .

Bohužel denní data před rokem 1971 nebyla $\mathrm{k}$ dispozici, proto je volatilita analyzována až od tohoto roku. Nicméně se nemusí nutně jednat o závažný nedostatek, nebot' oficiální nominální devizové kurzy byly před tímto obdobím fixovány, tudíž by během brettonwoodského období byly změny kurzů velmi malé či vůbec žádné.

Obrázek 2 zachycuje vývoj denních výnosů vybraných devizových kurzů. Je jasně vidět, že kolísání kurzů se odehrávalo v rozsahu maximálně několika setin nominální hodnoty kurzů měn vůči USD (resp. naopak, nebot' americký dolar vystupuje jako bazická měna). Nicméně vzhledem k obrovskému objemu denních devizových obchodů znamenají tyto, na první pohled marginální výchylky, značné změny hodnot aktiv subjektů angažovaných na těchto měnových trzích.

Dále můžeme pozorovat $u$ všech výnosů devizových kurzů existenci tzv. shluků volatility (volatility clustering). To znamená, že v historii výnosů se stř́idala období s nízkou volatilitou s obdobími vysoké volatility, přičemž at' už nízká, nebo vysoká volatilita má tendenci se shlukovat do časových úseků různé délky.

\footnotetext{
${ }^{5}$ Databáze FRED je dostupná zde:

http://research.stlouisfed.org/fred2/.
} 
$\mathrm{AUD} / \mathrm{USD}$

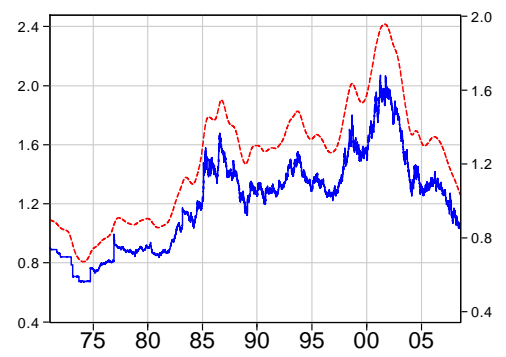

$\mathrm{DEM} / \mathrm{USD}$

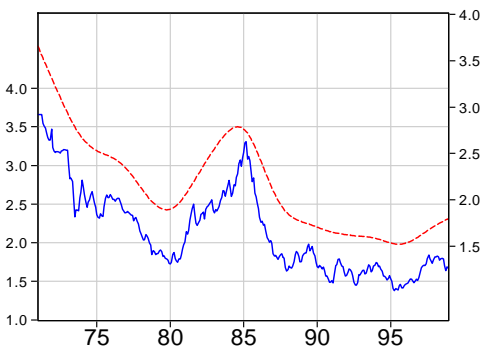

FRF/USD

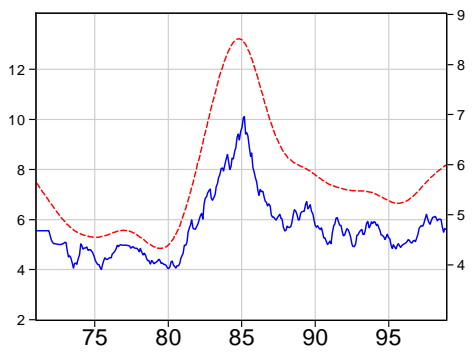

$\mathrm{SEK} / \mathrm{USD}$

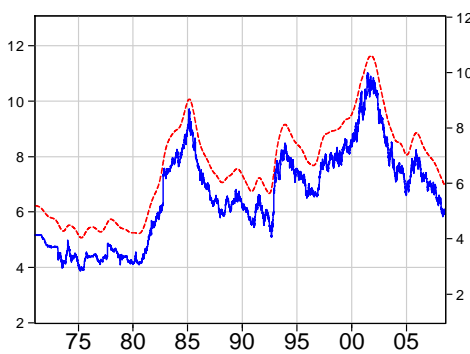

Zdroj: FRED, IFS, vlastní výpočty
$\mathrm{CAD} / \mathrm{USD}$

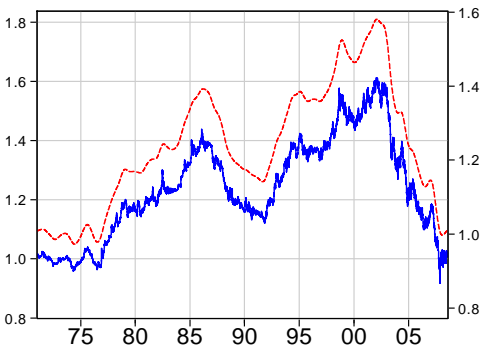

DKK/USD

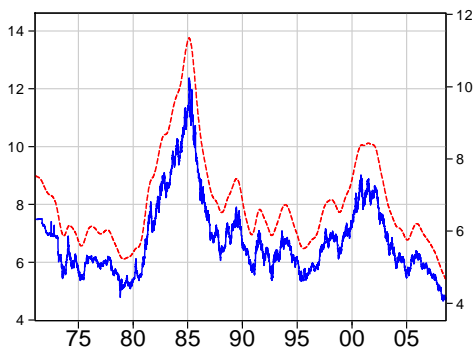

GBP/USD

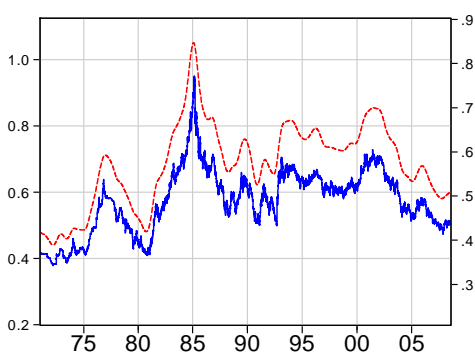

$\mathrm{CHF} / \mathrm{USD}$

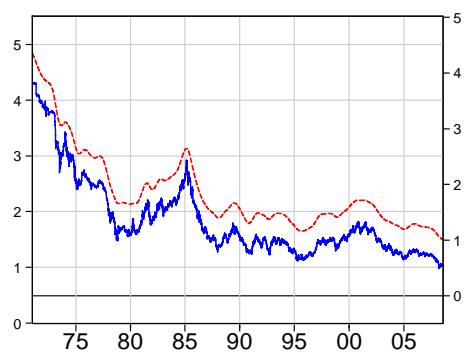

EUR/USD

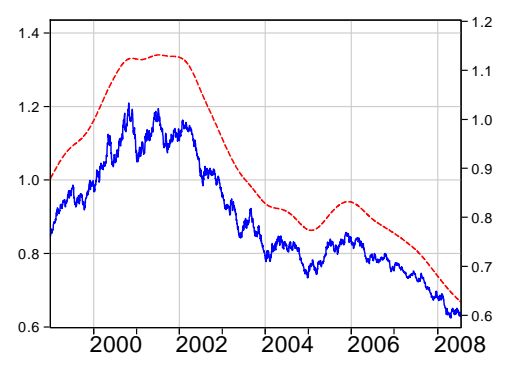

JPY/USD

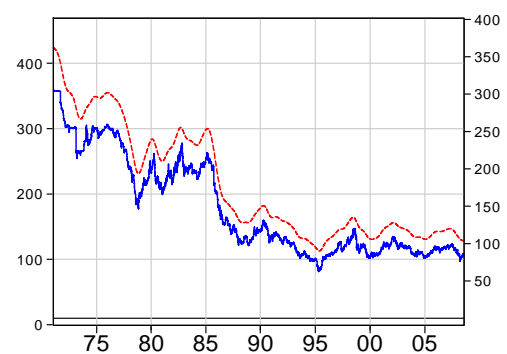

Obrázek 1 Vývoj vybraných devizových kurzů.

Na levé ose je vynesen vývoj časových řad kurzů. Na pravé ose je vynesena trendová složka časových řad, vypočtená pomocí H-P filtru $(\lambda=6812100)$. Délka zkoumaného období je od 4. 1. 1971 do 14. 7. 2008. Data jsou v denních frekvencích. Výjimkou jsou časové řady DEM (měsiční, konec dat k prosinci 1998), FRF (měsíční, konec dat k prosinci 1998) a EUR (denní, období 4. 1. 1998 - 14. 7. 2008).

Pokud jde o př́íiny volatility a jejího shlukování v určitých časových obdobích, je jasné, že prííčnných faktorů byla celá řada, a zcela jistě se nejednalo pouze o př́iciny ekonomického charakteru, ale také charakteru psychologického. Co můžeme prímo z grafu vyčíst, je to, že u většiny měn došlo k prudkému nárůstu volatility v roce $1985, \mathrm{tj}$. v období „přelomu“, kdy dolar po několikaletém prudkém růstu začal opět stejně strmě klesat. Další prudké změny rozkolísanosti měn jsou již u každé z nich poměrně 
AUD/USD

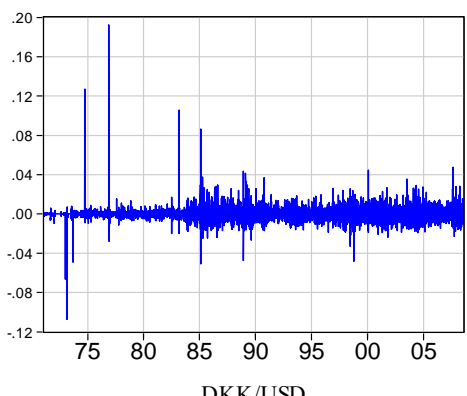

$\mathrm{DKK} / \mathrm{USD}$

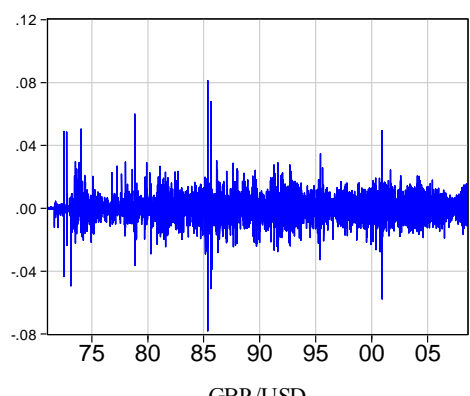

GBP/USD

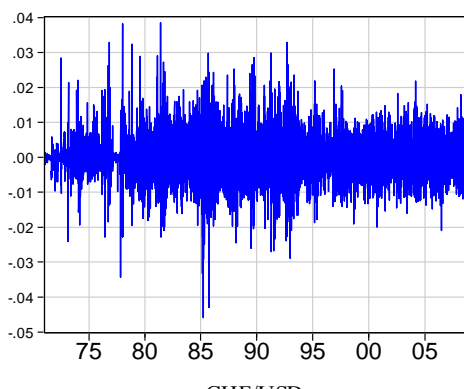

CHF/USD

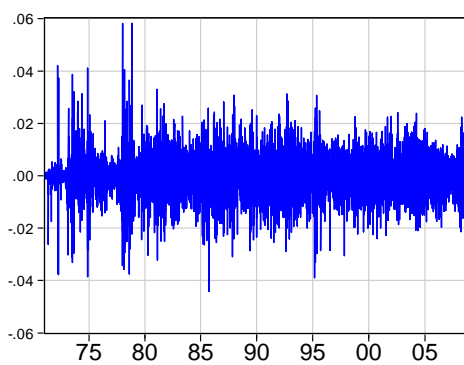

$\mathrm{CAD} / \mathrm{USD}$
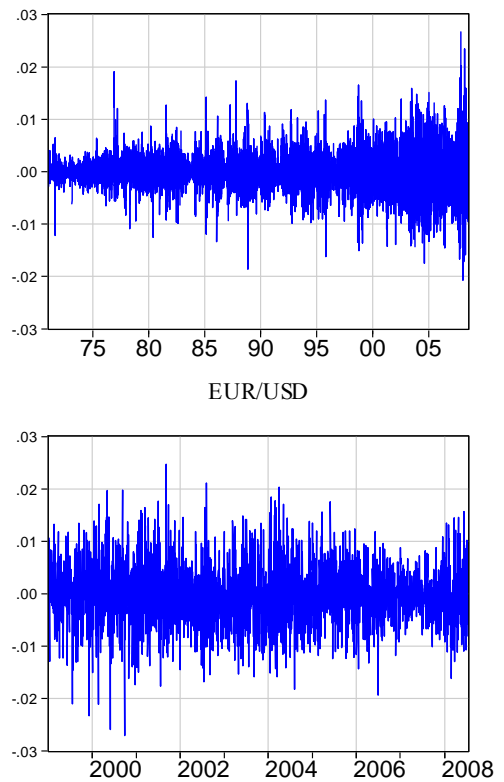

JPY/USD

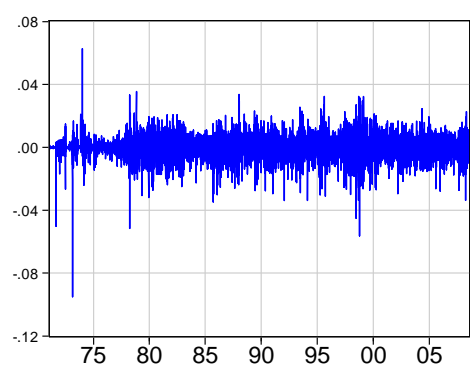

DEM/USD
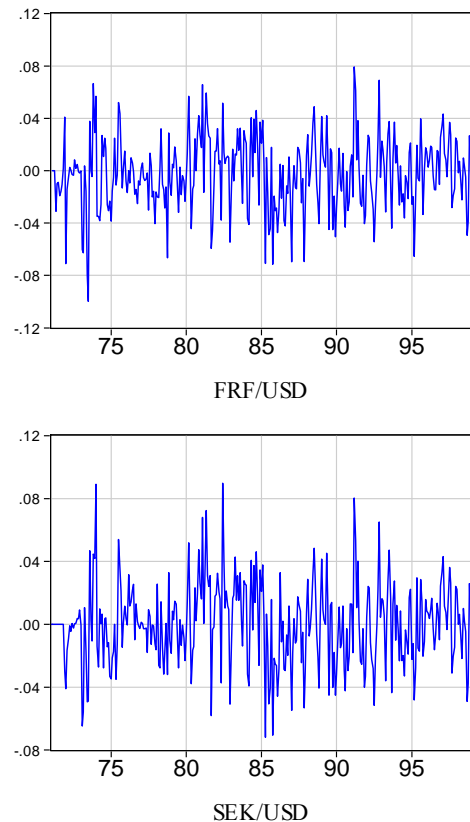

SEK/USD

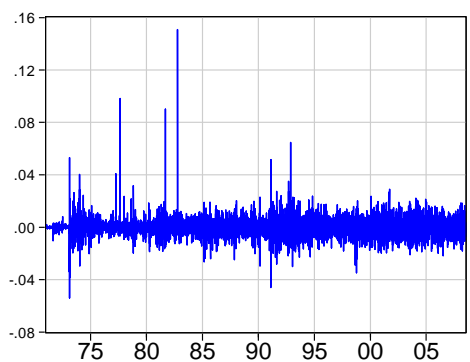

Zdroj: FRED, IFS, vlastní výpočty.

Obrázek 2 Vývoj výnosů vybraných devizových kurzů.

Délka zkoumaného období je od 4. 1. 1971 do 14. 7. 2008. Data v denních frekvencích. Výjimkou jsou časové řady DEM (měsíční, konec dat k prosinci 1998), FRF (měsíční, konec dat k prosinci 1998) a EUR (denní, období 4.1 .1998 - 14.7. 2008).

individuální. Výjimkou je období od počátku 2 poloviny roku 2007, kdy začala krize amerického trhu rizikových hypoték (sub-prime), která se následně přelila na všechny světové finanční trhy. Zvýšená volatilita je jasným ukazatelem nervozity investorů či spekulanti̊, kteří se nějakou formou angažují na měnových trzích.
Jako „alternativni“ pohled na vývoj volatility kurzů vybraných měn můžeme použít modely pro výpočet podmíněného rozptylu reziduí časových řad volatilitu na finančních trzích - viz obrázek 3 (výsledky regresí pro jednotlivé časové řady lze nalézt v príloze jako tabulku 1). 

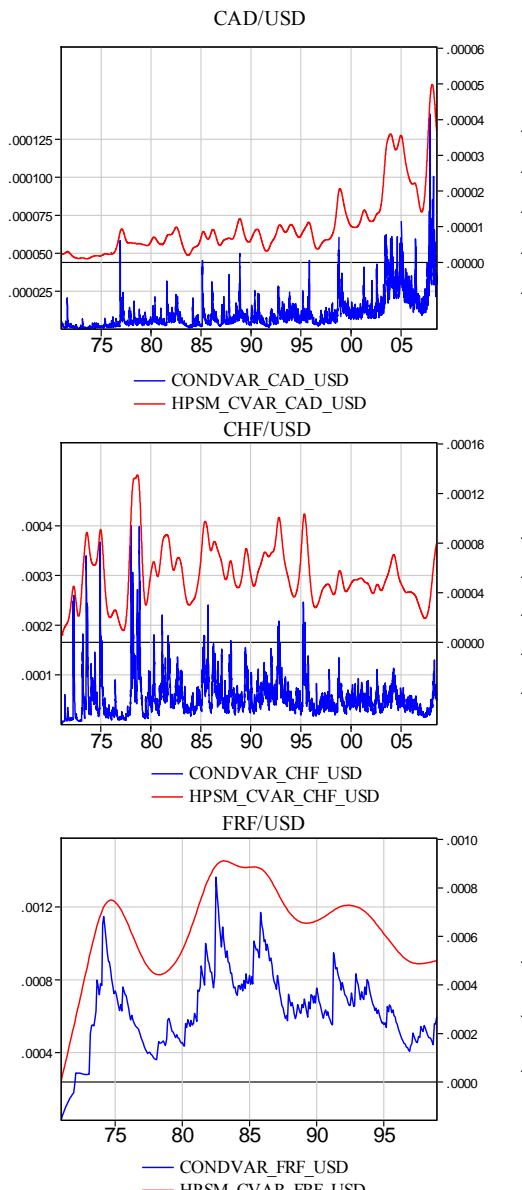

- HPSM CVAR FRF USD

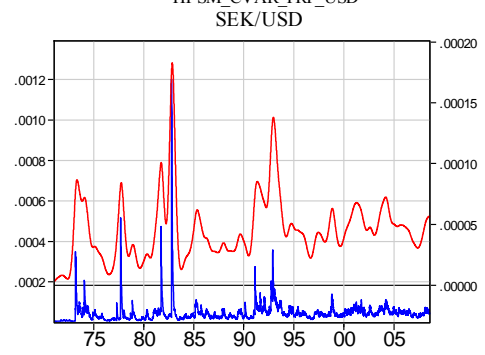

- CONDVAR_SEK_USD

— HPSM_CVAR_SEK_USD

Zdroj: FRED, IFS, vlastní výpočty.
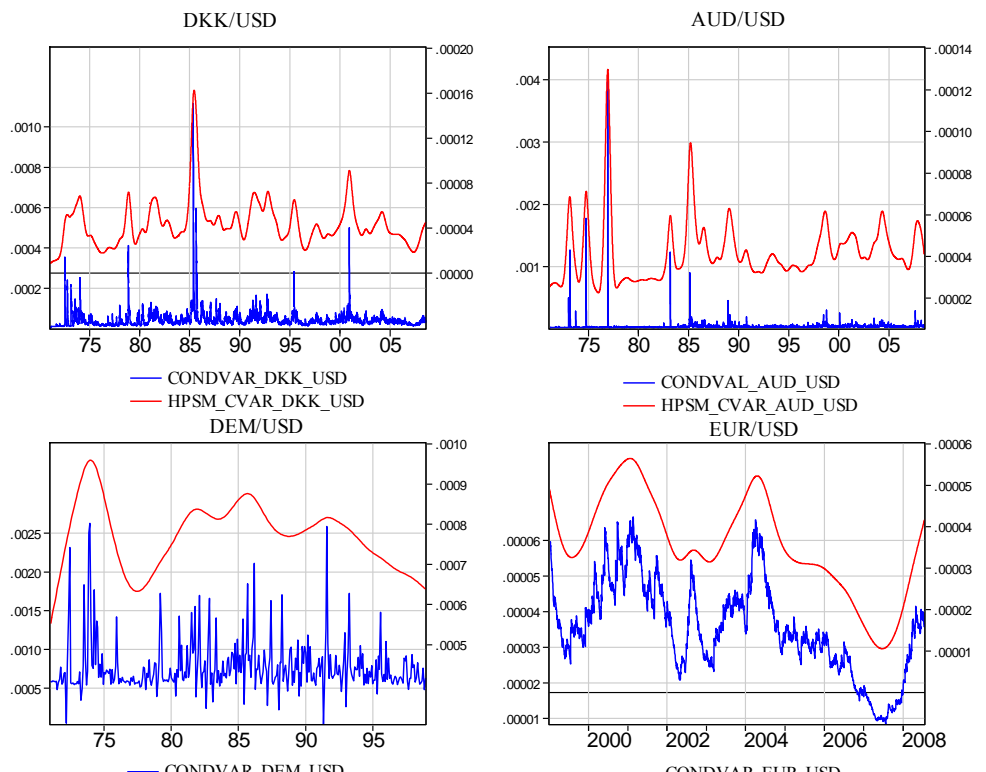$$
\begin{array}{cccc}
2000 & 2002 \quad 2004 \quad 2006 \quad 2008 \\
& - \text { CONDVAR_EUR_USD }
\end{array}
$$$$
\text { HPSM CVAR DEM }
$$
GBP/USD

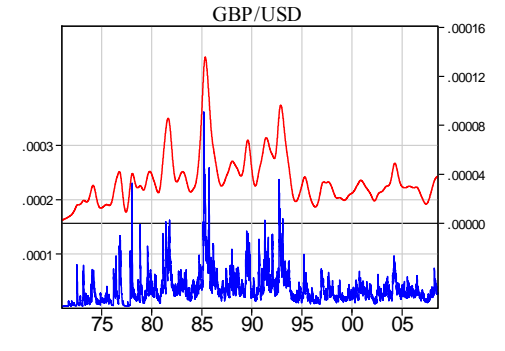

- CONDVAR_GBP_USD

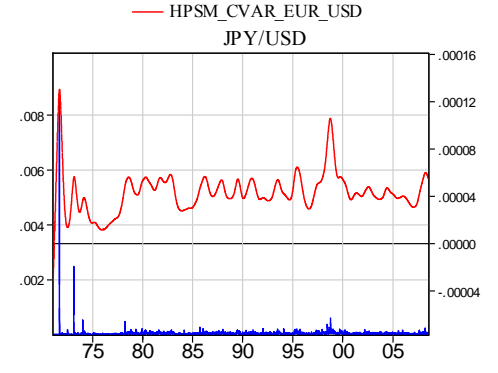

- CONDVAR_JPY_USD

Obrázek 3 Vývoj volatility výnosů vybraných devizových kurzů.

CONDVAR_(př́slušný kurz) označuje časovou řadu podmíněného rozptylu, tj. volatility. HPSM_CVAR_(př́slušný kurz) označuje filtrovanou časovou řadu podmíněného rozptylu. Pro filtrování byl použit H-P filtr, s s doporučenou hodnotou parametru $\lambda=6812100$. Délka zkoumaného období je od 4. 1. 1971 do 14. 7. 2008. Data v denních frekvencích. Výjimkou jsou časové řady DEM (měsíční, konec dat k prosinci 1998), FRF (měsíční, konec dat k prosinci 1998) a EUR (denní, období 4. 1. 1998 - 14. 7. 2008).

U všech časových řad (vyjma australského dolaru) je vidět jasný nárůst volatility zhruba od poloviny roku 2007.

Dále u kanadského dolaru je zřejmý dlouhodobý trend v nárůstu volatility. U ostatních měn volatilita osciluje s většími či menšími „ústřely“ kolem konstantní hodnoty, která je pro každý kurz jiná. Zajímavý ještě může být pohled na volatilitu kurzu GBP/USD, kdy po roce 1992, kdy Velká Británie byla nucena opustit evropský mechanismus směnných 
kurzů (exchange rate mechanism, ERM), došlo po značném a dočasném prudkém nárůstu volatility k jejímu značnému zklidnění, a to na úroveň, jež byla dokonce nižší než během období členství této země v ERM, a dokonce i před ním, přestože jak před, tak i po výstupu zERM měla režim volně plovoucího kurzu.

Závěrem této části tedy můžeme říci, že analýza volatility, at' už grafickým, nebo modelovým aparátem, ukázala (viz obrázek 3 a z něj vyplývající analýza), že post-brettonwoodské období se vyznačovalo značně zvýšenou volatilitou devizových kurzů, což samozřejmě vyplývá z podstaty užívaných režimů devizových kurzů.

Pokud přihlédneme $\mathrm{k}$ současnému vývoji na devizových trzích, řekněme od vypuknutí hypoteční krize v srpnu roku 2007, pak přestože většina devizových trhů indikuje nárůst volatility, nejedná se z historického hlediska o výjimečný vývoj. Toto platí, co se rozsahu (měřeno jako podmíněný rozptyl reziduí časových řad) volatility týče. Nicméně vzhledem k tomu, jakým obrovským pokrokem v období od 90 . let do současnosti nejenom devizové trhy prošly, může i nárůst volatility, jejíž úroveň (či rozsah) je „menšsi“ než $\mathrm{v}$ předchozích obdobích, znamenat značnou nejistotu a destabilizaci tohoto trhu. Rozvoj různých druhů finančních instrumentů, nárůst objemu obchodů na těchto trzích a vzájemná, stále rostoucí provázanost finančních trhů znamená, že tyto pak mohou být mnohem citlivější a bouřlivěji reagovat na těmito trhy negativně vnímané události.

\section{Závěr}

Cílem této práce bylo ukázat, že historický vývoj volatility kurzů AUD, CAD, DEM, DKK, EUR, FRF, GBP, JPY, SEK a CHF vǔči americkému dolaru (USD) byl na období zvýšené volatility poměrně bohatý, a tedy že současné období zvýšené volatility na vybraných měnových trzích není z tohoto pohledu ničím výjimečné.

Zdrojem dat byly databáze FRED Federální banky St. Louis a IFS Mezinárodního měnového fondu. Frekvence časových řad byla denní, s výjimkou kurzů DEM a FRF, které byly měsíční. Kromě kurzu eura byl rozsah pozorování v období 1971 až 2008.

Použita byla grafická a ekonometrická analýza výnosů časových řad devizových kurzů za pomoci modelů GARCH, resp. GARCH-in-Mean.

Pokud jde o samotný vývoj úrovní devizových kurzi̊, pak lze říci, že všechny měny vykazovaly během zkoumaného období přibližně od 2. poloviny roku 2001 apreciační trend vůči USD. Jejich vývoj pak také naznačuje poměrně jasné př́znaky cykličnosti.
Grafickou analýzou vývoje výnosů časových řad, resp. analýzou podmíněného rozptylu vypočteného za pomoci modelů GARCH, jsme zjistili, že u všech zkoumaných kurzů se vyskytovala období zvýšené volatility (volatility clustering) a vývoj na měnových trzích po vypuknutí finanční krize ve 2 . polovině roku 2007 není výjimkou, co se rozsahu či ,velikosti“ volatility týče.

Nicméně je třeba zdůraznit, že přestože je nárůst volatility na zhruba stejných, nebo dokonce menších úrovních než byl v minulosti, jeho př́činy a zejména důsledky jsou zcela odlišné. $O$ př́činách velkého nárůstu nervozity na měnových trzích není třeba dlouze diskutovat - finanční a v současné době již i reálná hospodářská krize byla spuštěna masivním poskytování podřadných (sub-prime) hypoték a masivním celosvětovým investováním do finančních derivátů navázaných na výnosy $\mathrm{z}$ těchto hypoték, tj. na jejich splácení dlužníky.

Pokud jde o následky, nebo možná lépe o náklady zvýšené volatility, pak ty, přestože je její rozsah (ve smyslu porovnání s historickým vývojem) stejný, nebo i menší než byla minulá maxima, mohou být i značně vyšší. Důvodem je prudký nárůst provázanosti trhů oproti minulosti, celková globalizace a prohloubení světových finančních trhů, co se třeba objemu obchodů týče. Proto i relativně malý nárůst oscilace kurzů kolem jejich střední hodnoty může znamenat poměrně velký nárůst transakčních nákladů firem, které se snaží proti výchylkám kurzů zajišt'ovat.

\section{Literatura}

ARLT, J., ARLTOVÁ, M. (2007). Ekonomické časové rady. Praha: Grada Publishing.

ARLT, J., ARLTOVÁ, M. (2003). Finanční časové $\check{r}$ ady. Praha: Grada Publishing.

BOLLERSLEV, T. (1986). Generalized Autoregressive Conditional Heteroskedasticity. Journal of Econometrics 31 (1): 307-327. http://dx.doi.org/10.1016/0304-4076(86)90063-1

CADY, J., GONZALES-GARCIA, J. (2006). The IMF's Reserves Templates and Nominal Exchange Rate Volatility. IMF Working Paper WP/06/274.

ENGLE, R.F. (1982). Autoregressive Conditional Heteroskedasticity with Estimates of the Variance of United Kingdom Inflation. Econometrica 50 (1): 9871007. http://dx.doi.org/10.2307/1912773

ENGLE, R.F., LILIEN, D.M., ROBINS, R.P. (1987). Estimating Time Varying Risk Premia in the Term Structure: the ARCH-M Model. Econometrica 55 (1): 391-407. http://dx.doi.org/10.2307/1913242

KALRA, S. (2008). Global Volatility and Forem Returns in East Asia. IMF Working Paper WP/08/208. 
KISINBAY, T. (2003). Predictive Ability of Asymmetric Volatility Models at Medium-Term Horizons. IMF Working Paper WP/03/131.

PALMA, W. (2007). Long-Memory Time Series: Theory and Methods. Hoboken: Wiley. http://dx.doi.org/10.1002/9780470131466
STANČÍK, J. (2007). Determinants of Exchange-Rate Volatility: The Case of the New EU Members. Czech Journal of Economics and Finance 57(9-10): 414432. 


\section{Př́lohy}

Tabulka 1 Výsledky modelů volatility vybraných devizových kurzů

\begin{tabular}{|c|c|c|c|c|c|c|c|c|}
\hline \multirow{2}{*}{$\begin{array}{l}\text { Výnosy } \\
\text { kurzů/Typ } \\
\text { modelu }\end{array}$} & \multicolumn{8}{|c|}{ GARCH } \\
\hline & Konstanta & $\varepsilon_{(t-1)}^{2}$ & $\varepsilon_{(t-2)}^{2}$ & $\varepsilon_{(t-3)}^{2}$ & $\varepsilon_{(t-4)}^{2}$ & $\varepsilon_{(t-5)}^{2}$ & $\delta_{(t-1)}^{2}$ & $\delta_{(t-2)}^{2}$ \\
\hline AUD/USD & $0.0000 * *$ & $0.1077 * * *$ & - & - & - & - & $0.7210 * * *$ & - \\
\hline $\mathrm{CAD} / \mathrm{USD}$ & 0.0000 & $0.1430 * * *$ & $-0.1833 * * *$ & $0.0424 * *$ & - & - & $1.8578 * * *$ & $-0.8598 * * *$ \\
\hline DEM/USD & $0.0005 * * *$ & 0.0438 & $-0.0866 * * *$ & 0.0248 & 0.0650 & $0.2723 * * *$ & - & - \\
\hline DKK/USD & $0.0000 * * *$ & $0.0837 * * *$ & - & - & - & - & $0.8921 * * *$ & - \\
\hline $\mathrm{EUR} \mathrm{USD}^{\mathrm{a})}$ & - & $0.0215 * * *$ & - & - & - & - & $0.9786 * * *$ & - \\
\hline FRF/USD & $0.0000^{*}$ & $0.0500 *$ & - & - & - & - & $0.9156^{* * *}$ & - \\
\hline GBP/USD & $0.0000 * *$ & $0.0852 * * *$ & - & - & - & - & $0.9119 * * *$ & - \\
\hline JPY/USD & $0.0000 * *$ & $0.1355 * * *$ & - & - & - & - & $0.8514 * * *$ & - \\
\hline SEK/USD & $0.0000 *$ & $0.0518^{* * *}$ & - & - & - & - & $0.9503 * * *$ & - \\
\hline $\mathrm{CHF} / \mathrm{USD}$ & $0.0000 * * *$ & $0.0783 * * *$ & - & - & - & - & $0.9143 * * *$ & - \\
\hline
\end{tabular}

Modely volatility kurzů JPY/USD, GBP/USD, FRA/USD, DEM/USD, CAN/USD, AUD/USD musely být upraveny autoregresními a/nebo moving-average členy.

a) Počítáno metodou GARCH-in-Mean. 